\title{
頣下部と顎下部に同時に発生した皮様囊胞例
}

\author{
森園 健介・西元 謙吾・牛飼 雅人・宮之原郁代 \\ 松崎 勉・松根 彰志・黒野 祐一
}

\section{A Patient with Double Dermoid Cysts Occurring in Submental and Submandibular Spaces}

\author{
Kensuke Morizono, Kengo Nishimoto, Masato Ushikai, Ikuyo Miyanohara, \\ Tsutomu Matsuzaki, Shoji Matsune and Yuichi Kurono \\ (Kagoshima University)
}

\begin{abstract}
A dermoid cyst is one of the most common head and neck cystic diseases and is usually found in the submandibular area. We report a rare case of double dermoid cysts that occurred in submental and submandibular spaces at the same time in a 53-year-old woman who visited our hospital with the chief complaint of cervical swelling. MRI and CT scans revealed two tumors in the submental and submandibular spaces. The submandibular tumor had a calcified lesion. The two tumors were removed under general anesthesia. The submental tumor strongly adhered to connective tissue such as muscles and the hyoid bone. No adhesion to the surrounding tissues was observed in the submandibular tumor. Both tumors had a white muddy substance in the inside and were diagnosed as epidermal type dermoid cysts histopathologically.
\end{abstract}

Key words : dermoid cyst, submentum, submandible, head and neck tumor

はじめに

頋下部执よび買下部には種々の囊胞性疾患が発生し， そのなかで鑑別する疾患の一つに皮様囊胞 (dermoid cyst) がある.これは胎生期に迷入した外肧葉組織から 発生するものであり，その多くは単発性に発生する.今 回われわれは願下部执よび顎下部に同時に認められたき わめてまれな多発珄皮様襄胞の 1 症例を経験したので, ここに若干の文献的考察を加えて報告する.

\section{症例}

患者: 53歳, 女性.

主訴 : 左䫇下部腫瘤.

既往歴 : 特記すべき事項なし.

家族歴：特記すべき事項なし.

現病歴 : 20歳頃より頃下部に腫瘤を認めていた。しか
し，疼痛などの自覚症状を認めなかったため放置してい た. 平成 9 年頃より腫瘤の増大傾向を認めたため, 近医 を受診した．願下部に腫瘤が認められたため，精査目的 に当科紹介受診となった。

初診時所見：頸部正中よりやや左側に直径 $40 \times 30$ $\mathrm{mm}$ の弾性軟な腫瘤を認めた．舌骨との瘉着がやや認め られたが，可動性は良好であった．また左顩下部に直径 $10 \mathrm{~mm}$ の弾性硬な腫瘤を認めた(図 1 ).

画像所見：超音波検查上，頋下部の腫瘤に一致して直 径 $38 \times 17 \mathrm{~mm}$ の低エコー領域を認めた. MRI では願下 やや左側に T1 で等信号, T2 で高信号, 造影効果を認 めない腫瘤が認められた(図 $2 \mathrm{a}$ )。CT では左舌下部， 䫇舌骨筋・願舌骨筋下方の願部に $4 \mathrm{~cm}$ 大の内部均一な 囊胞性の腫瘤を認めた（図 3 a)．そこで超音波下に願下 部の腫瘤を試験穿刺したところ，白色のアテローム様の 


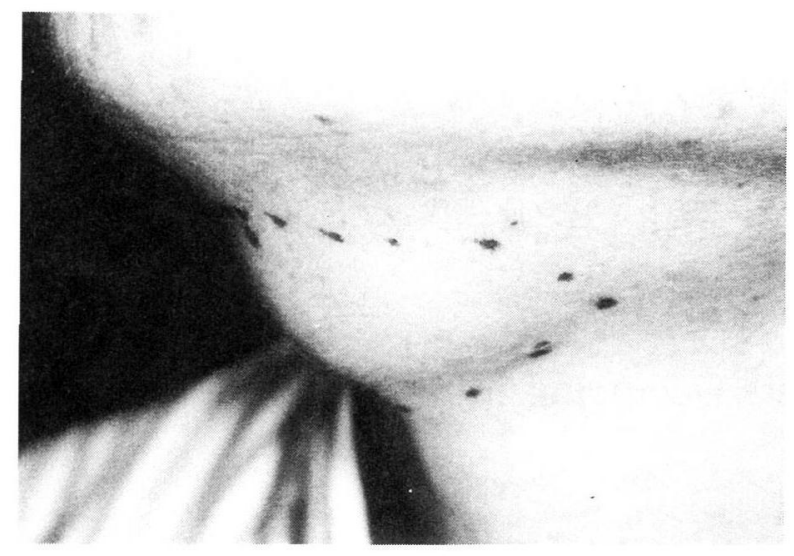

図 1 顎下部所見

写真中の点線は腫瘍の外縁を示す.

物質を吸引した。

顎下部の腫瘤に対して牟田氏法によるX線検査を行っ たところ左顎下部に石灰化像が認められた。超音波検査 でも顎下腺に隣接する，周囲の石灰化を伴ら腫瘤を認め
た. MRI 上左顎下部には $\mathrm{T} 1$ 等信号, $\mathrm{T} 2$ 高信号, 造影 効果を認めない腫瘍が認められた(図 2 b). CTでは左 顎下腺内にも $1 \mathrm{~cm}$ 大の囊胞性の腫瘤を認めた(図 $3 \mathrm{~b}$ ).

以上の所見より, 頣下部の腫瘤は皮様囊胞, 左顎下部 の腫瘤は反応性のリンパ節腫大と考光, 平成 10 年 5 月 11 日，全身麻酔下にそれぞれの腫瘤摘出術を行った。

手術所見: 頃下部に約 $4 \mathrm{~cm}$ の水平な切開を加光, 頣 下部の腫瘤を周囲の筋・結合織から剥離した。腫瘤は周 囲の筋・結合織と強く癒着して和り，さらに舌骨との癒 着も認められた。そこで舌骨の一部を切離した上で，腫 瘤を周囲の筋・舌骨の一部とともに一塊として摘出した.

次に左顎下腺内方を触診すると, 直径 $1 \mathrm{~cm}$ 大のやや 固い薄い被殼を持つ腫瘤が認められた。視野を確保する ため皮切を外方へ $1 \mathrm{~cm}$ 程度延長し，左顎下腺の内方に ある腫瘤を摘出した。周囲組織との癒着は認められず腫 瘤の摘出は容易であった，創部の止血操作を行い，皮膚 を縫合して手術を終了した。

摘出した 2 つ腫瘤はそれぞれ $56 \times 30 \times 14 \mathrm{~mm}, 19$ $\times 14 \times 10 \mathrm{~mm}$ 大であり，これに割を入れると，両方と

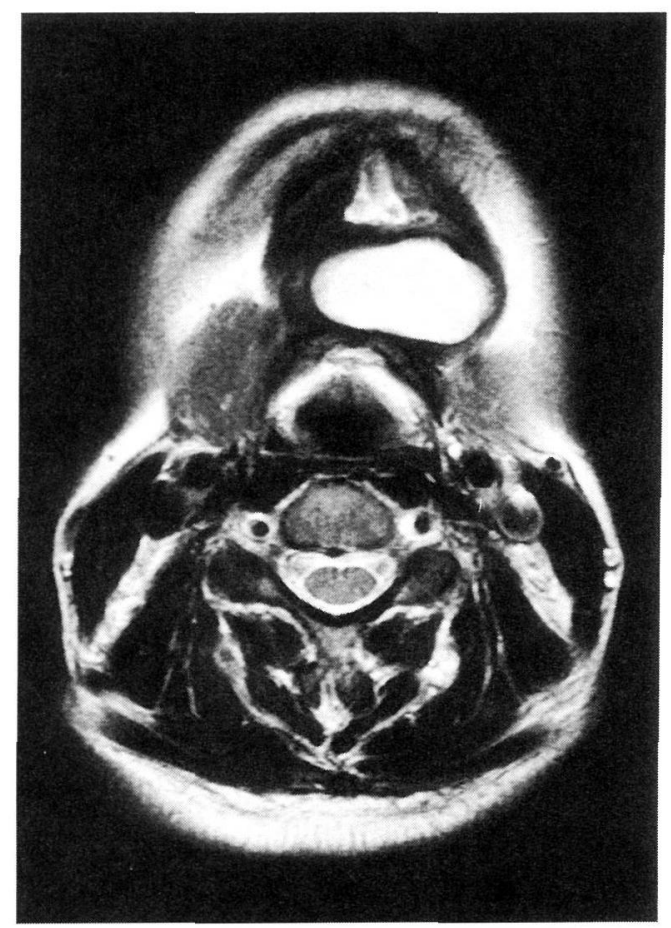

a

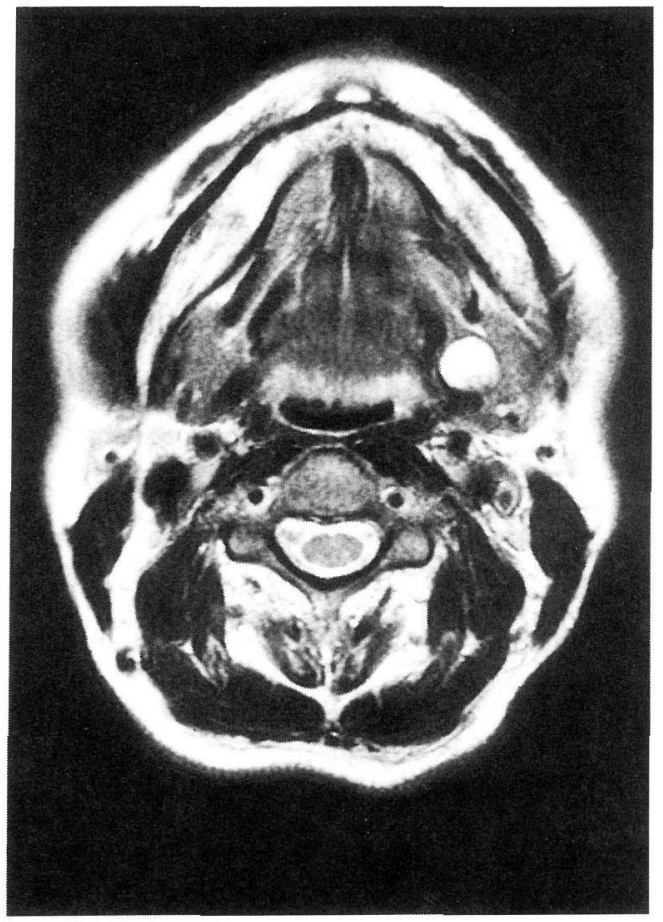

b

図 $2 \mathrm{MRI}$ ( T2 強調水平断像)所見

a . 䫀下部の腫瘤を示す.

b. 左顎下部の腫瘤を示す。 


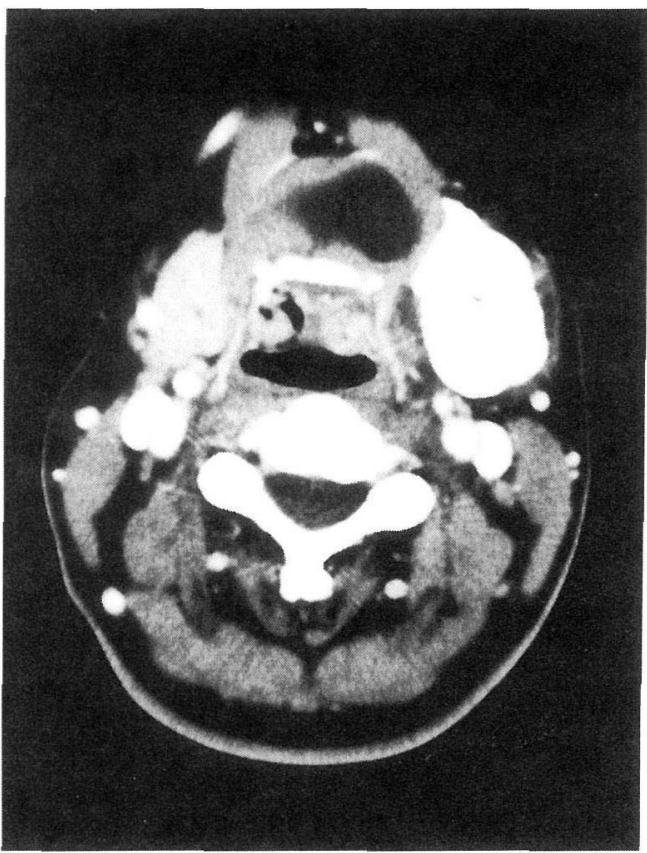

a

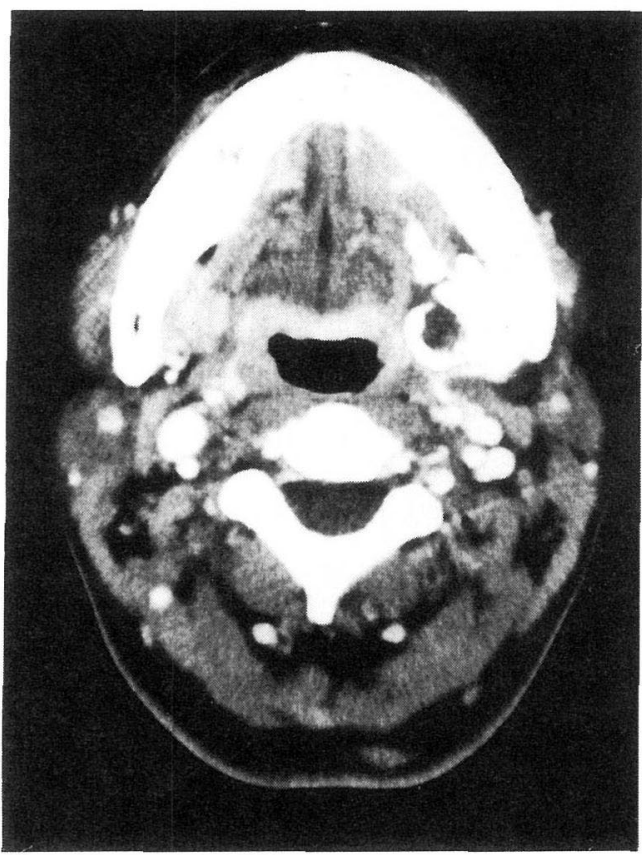

b

図 3 CT 所見

a 、願下部の腫瘤, 石灰化は認められない。

b. 左顎下部の腫瘤, 腫瘤周囲に石灰化を認るる.

も白色泥状の内容物を認めた(図 4).

病理所見 : 願下部の腫瘤は扁平上皮で裏打らされた鞟 胞状であり, 内部は horney lamellar material で満たさ れていた。慢性炎症性細胞や多核巨細胞が切開部周囲に 浸潤していたが，明らかな皮膚付属器官の存在は認めら れなかった(図 $5 \mathrm{a})$. 病理組織学的には類表皮型の皮様 豊胞と診断された.

左顎下部の腫瘤は骨様の石灰化を伴らヒアリン結晶の

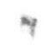

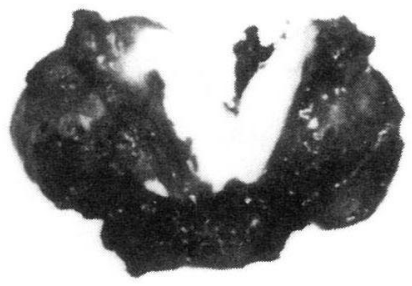

図 4 摘出標本

いずれの腫瘤も割を入れると内部に白色泥状の物質を認 めた。
組織が認められ(図 5 b), これも同じく病理組織学的に 石灰化を伴った類表皮型の皮様囊胞と診断された。

\section{考察}

皮様囊胞の発生部位としては，New ら ると全身的に発生を認めるが，特に肛門を含も直腸部分 や卵巣に多く認められ，この両者だけで全体の $85 \%$ 以上 を占める、頭頸部での発生はそれ以外の部位としては最 も多く認められるが，それでも6.9\%にすぎない、口腔 領域のなかでは口腔底部に発生するものが多い、口腔底 部に発生したものに対して，Bergmann ${ }^{2)}$ は(1)顎舌骨筋 の上方に存在する舌下型, (2)顎舌骨筋の下方に存在する 頣型を提唱し, 萩崎 ${ }^{3)}$ は(3)顎舌骨筋の上下に存在する舌 下臨型を追加して 3 型に分類している。また萩崎引はは 腔底の正中線上にあるものを正中線型, 左右に偏位する ものを側方型とする分類も示している. 今回の症例は顎 舌骨筋よりも下方に囊胞が認められたため覧型に当たり， それぞれ正中線型拉よび側方型であったと思われる。

口腔底に発生する皮様囊胞 (dermoid cyst) は Meyer ${ }^{4)}$ によって病理組織学的な特徵から 3 型に分類されている. 


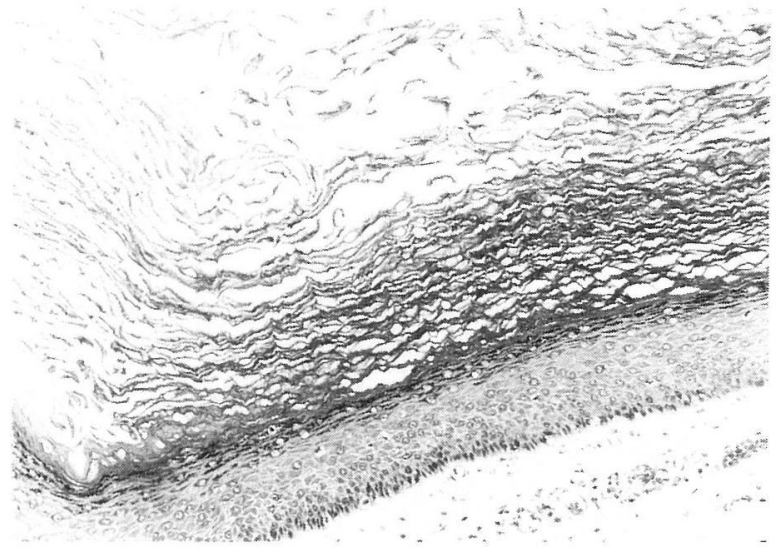

a

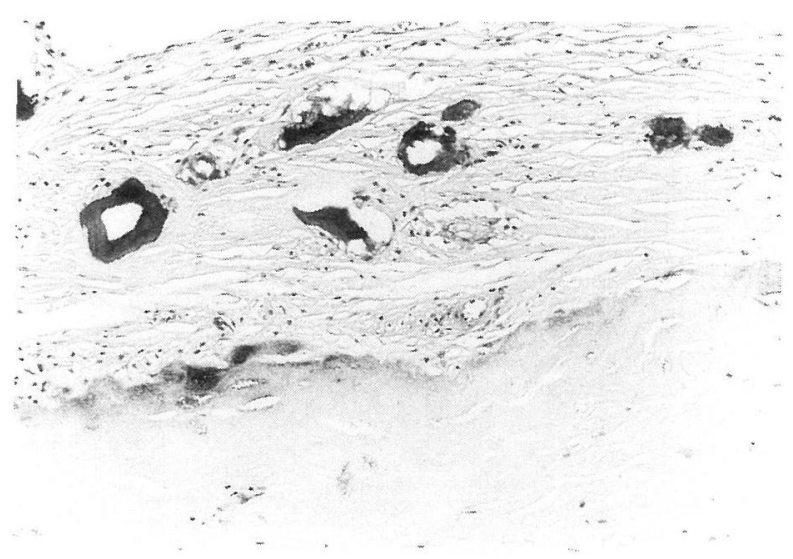

b

図 5 病理所見 $(\mathrm{HE}$ 染色, 800倍)

a . 願下部の腫瘤：囊胞内挖を裏打ちする扇平上皮と horney lamellar material の存在を認める.

b．左顎下部の腫瘤：骨様の石灰化を伴らヒアリン結晶が認められる.

I 型は類表皮囊胞 (epidermoid type) と呼ばれ，䡛胞壁 は重層扁平上皮の皮様構造を示し, その内容物は表皮剥 離首やコレステリンなどを含省灰白色の泥状物質などで 西り, 皮膚付属器官は認められない、而型はいわゆる類 皮囊胞 (dermoid type) と呼ばれるもので, 襄胞壁は類 表皮囊胞と同様に重層扁平上皮の皮様構造を示し, 内容 物としては皮脂腺, 汗腺, 毛襄などの皮膚付属器官を有 するものである. II 型は奇形腫型 (teratoid type) と呼ば れ, 皮虐付属器以外飞中肧葉, 下肧葉成分が含まれる奇 形腫様のものである。ただし，奇形腫型に関してはその 報告は少なく，矢の存在が疑問視されている。萩場ら ${ }^{5}$ は上記の III型の上らな病変は肧細胞由来の成熟型奇形腫 とみなし，矢の発生に上皮成分の迷入が考觉られている I 型，II型とは分けて考党るべきと指摘している．今回 の症例では病理学的には囊胞壁が扁平上皮で裏打ちされ て扮り, 皮膚付属器官等の存在は認められなかったこと から類表皮霅胞に当たると思われる.

皮様囊胞の発生機序としてNew ら (1) $^{1}$ (1) congenital dermoid cysts of teratoma type, (2)acquired implantation dermoid cysts, (3)congenital inclusion dermoid cysts といら 3 型に分類している。このうち頸部でよく認 められるものとしては congenital inclusion dermoid cysts が考光られている. その発生機序に関して Bergmann ${ }^{2)}$ は胎生期の鰓弓癒合部へ外肧葉が迷入することで説明し ている、したがって今回の症例で贿下部に発生したもの 飞関しては第 1 鰓弓・第 2 鰓弓の正中癒合線での上皮の
迷入が考学られる。左顎下部に発生したものに関しては 鰓裂溝の癒合の際に上皮が迷入乙たものと考兄られる.

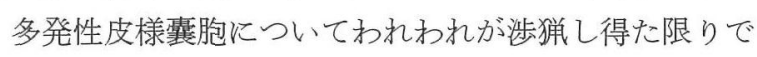
は比較的まれであり, 岩田ら ${ }^{6)}$ の13例, 有村ら 7 の 3 例 の報告を認める限りである。こうした同時多発症例に対 し, 覚道ら ${ }^{8)}$ は複数の上皮塊が偶然同時に迷入するか, もしくは迷入した単発の上皮塊がいくかに分かれて発 育した可能性を示唆している。自験例では，それぞれの 裹胞がまったく異なった位置に独立して存在して沶り連 絡性も認められなかったことから, 前述したごとく複数 の上皮塊が迷入した可能性が高いと思われた。

今回, われわれは診療の過程でさまざまな画像を撮影 したが, 病変部の描出といら点に批いては, MRIがもっ とも優れていた。これは MRIでは CT と比べて歯牙の 充填物や骨・空気などによるアーチファクトが少ないこ とや，軟部組織間のコントラストが強くつくことによる とされている9)、ただ今回の症例では触診上で腫瘤の硬 度に違いがあり，旮れぞれの腫瘤が異なる病変と考兄ら れ, その診断は必ずしも容易ではなかった。

皮様豊胞に対しては一般的に囊胞の全摘が行われる. もし残存した場合再発は必発であるとされている10). 一 般的に予後は良好で悪性化はまれであるといわれている。 今回の症例では現在のところ囊胞の再発は認めていない が，多発性注生じる場合は潜在する腫瘤を取り残す可能 性も亦り注意が必要と思われる。 


$$
\text { まとめ }
$$

頋下部および擷下部に同時に多発した皮様囊胞の 1 例 を報告した．皮様囊胞は比較的よくみられる症例である が，本症例のごとくまれに多発することを考慮し，診断 ならびに治療を行らことが必要と考兄られた。

\section{参考文献}

1) New GB and Erich JB : Dermoid cysts of the head and neck. Surg Gynec Obstet 65 : 48 55, 1937.

2) Bergmann E : Handbuch der Practische Chirurgie. 4 umgearb Auf1 (ed by von Bruns). pp 976 979, Enke, Stuttgart, 1913-1914.

3 ）萩崎為行：巨大なる口腔底皮様裳腫の一例。耳喉 2:562 $\sim 569,1929$.

4 ) Meyer I : Dermoid cysts (Dermoids) of the floor of the mouth. Oral Surg $8:$ 1149 1164, 1955.

5 ）萩場貴夫, 伊藤和也, 和田 清, 他：口腔底に生じた類皮
囊胞の一症例. 耳鼻臨床 補38：215 219, 1990.

6 ）岩田浩行, 高井克喜, 丹下和久, 他：オトガイ下部にみら れた多発性類表皮喗胞の 1 例. 日口外誌 $33: 773 \sim 776$, 1987.

7 ）有村健二, 向井 洋, 石神哲郎, 他 : 過去 25 年間の類皮囊 胞及び類表皮霊胞の臨床統計的観察. 日口外誌 $38: 1441$ $\sim 1442,1992$.

8 ）覚道健治, 荒木春美, 大竹智子, 他: 上唇に発生した類皮 打よび類表皮䡛胞の 1 例. 日口外誌 $32 ： 1238 \sim 1243,1986$.

9 ) 山邊けい子, 西川育志, 本田雅之, 他: 口腔底類表皮囊胞 の 2 例. 耳鼻臨床 $81 ： 235 \sim 240,1988$.

10）高木拱夫, 本村昌一, 大沼秀行, 他 : Dermoid Cyst. 耳 喉 $58: 312 \sim 313,1986$.

$$
\left.\begin{array}{l}
\text { 原稿受付 : 平成 } 12 \text { 年 } 3 \text { 月 } 6 \text { 日 } \\
\text { 原稿採択 : 平成 } 12 \text { 年 } 4 \text { 月 } 26 \text { 日 } \\
\text { 別刷請求先 : 森園健介 } \\
\text { 个 } 890-8520 \text { 鹿児島市桜 } r \text { 丘8-35-1 } \\
\text { 鹿児島大学医学部耳鼻咽喉科学教室 }
\end{array}\right)
$$

